\title{
Chemical composition of the sediment from Lake 20 (Antarctica)
}

\author{
Renato BAUDO*, Paola BARBERO, Monica BELTRAMI and Daria ROSSI \\ CNR - Istituto Italiano di Idrobiologia, L.go Tonolli 50, 28922 Verbania Pallanza, Italy \\ *e-mail corresponding author: r.baudo@iii.to.cnr.it
}

\begin{abstract}
Lake $20\left(19,000 \mathrm{~m}^{2}\right)$ is located on the coast of the Ross Sea, in the North-Central part of Victoria Land, and its surface is ice-free between the end of December and early February. Within the framework of the Italian National Research Programme in Antarctica, a study was made of the chemical composition of sediments from the lake, with the intention of using this information to contribute to a better understanding of the processes involved in the long range transport of pollutants and their role in global changes. A sediment core from Lake 20 (Antarctica), $18 \mathrm{~cm}$ long, was collected in 1994, sliced into $2 \mathrm{~cm}$ sections and analysed using X Ray fluorescence spectrometry for 17 elements ( $\mathrm{Si}, \mathrm{Al}, \mathrm{Ca}, \mathrm{K}, \mathrm{Fe}, \mathrm{Mg}, \mathrm{Ti}, \mathrm{S}, \mathrm{P}, \mathrm{Pb}, \mathrm{Zn}, \mathrm{Cu}, \mathrm{Ni}, \mathrm{Mn}, \mathrm{Cr}, \mathrm{Na}, \mathrm{Cl}$ ), by CHN Elemental Analyser for $C$ and $N$, by Flameless Atomic Absorption Spectrometry for As, and by Cold Vapour Atomic Absorption Spectrometry for Hg. The chemical composition of the sediments is consistent with the known geochemical characteristics of the drainage basin. While the chemical analyses reveal that sedimentation in Lake 20 has changed through time, the variations along the core are most probably related to the climatic evolution of the area, to the consequent changes in weathering processes, and possibly to an increase in the primary productivity of the lake, rather than to anthropogenic influences on the biogeochemical cycles of the elements.
\end{abstract}

Key words: trace elements, sediments, Antarctica

\section{INTRODUCTION}

The continent of Antarctica may generally be regarded as a cold desert (Heywood 1984), with $98 \%$ of the land covered by ice; even in the warmest area, the temperature seldom exceeds $0{ }^{\circ} \mathrm{C}$, and monthly mean temperatures range from -12 to $+0.5^{\circ} \mathrm{C}$. Few areas of the continent therefore contain inland waters; those which are present were either left after the last glacial retreat, or formed by tectonic-volcanic activities (Heywood 1984).

Nevertheless, the existing lakes and pools are particularly interesting from a physical, chemical, and biological point of view, since they share some peculiar characteristics: well-defined boundaries, limited biodiversity, prolonged isolation from external influences due to the long duration of the ice-cover (Heywood 1984).

For this reason, within the framework of the Italian National Research Programme in Antarctica (started in 1985), the Istituto Italiano di Idrobiologia of the National Research Council has been carrying out a study of lakes in Antarctica (Guilizzoni et al. 1991, 1992; Libera 1993), to describe the limnological characteristics of about 60 different waterbodies from these remote areas.

Part of this study involved research on the chemical composition of the sediments from a few lakes, with the intention of using this information to contribute to a better understanding of the processes involved in the long range transport of pollutants and their role in global changes.

This paper reports the results of the inorganic chemical analysis of a sediment core collected in Lake 20, on the coast of the Ross Sea, in the North-Central part of Victoria Land; it is the largest $\left(19,000 \mathrm{~m}^{2}\right)$ of the investigated lakes in the area of Tarn Flat. It is located in a cryptodepression (-70 $\mathrm{m}$ a.s.1.), at $74^{\circ} 58^{\prime} \mathrm{S}$ latitude and $162^{\circ} 30^{\prime} \mathrm{E}$ longitude, has a maximum depth of 3.5 $\mathrm{m}$, and is fed by a small glacier $\left(0.3 \mathrm{~km}^{2}\right)$ in the watershed (2 $\mathrm{km}^{2}$; Libera 1993).

Previous studies (Guilizzoni et al. 1991, 1992) indicate that the lake surface is ice free between the end of December and early February, and different samples taken during melting time show a marked increase in the ionic content of the lake water (Tabs 1,2). Furthermore, the water chemistry shows the influence of sea spray, since sodium and chloride are the main ions and the $\mathrm{Na} / \mathrm{Cl}$ ratio $(0.93)$ is close to the value for sea water (0.86).

\section{MATERIAL AND METHODS}

The bottom of Lake 20 is covered by a thick algae mat, over a limy sediment with some sand and a low content of vegetal material. No benthic fauna was observed (Guilizzoni et al. 1991).

In January 1994, a core $18 \mathrm{~cm}$ long was collected in the centre of the lake, at the maximum depth, using a gravity corer. The core was immediately frozen ( -30 ${ }^{\circ} \mathrm{C}$ ) and taken back to the laboratory in Italy, where it was sliced into $2 \mathrm{~cm}$ sections.

A subsample of each section was then dried at 60 ${ }^{\circ} \mathrm{C}$, homogenised, and analysed by $\mathrm{X}$ Ray Fluorescence Spectrometry for 17 elements ( $\mathrm{Si}, \mathrm{Al}, \mathrm{Ca}, \mathrm{K}, \mathrm{Fe}, \mathrm{Mg}, \mathrm{Ti}$, $\mathrm{S}, \mathrm{P}, \mathrm{Pb}, \mathrm{Zn}, \mathrm{Cu}, \mathrm{Ni}, \mathrm{Mn}, \mathrm{Cr}, \mathrm{Na}, \mathrm{Cl}$ ), by CHN Elemental Analyser for $\mathrm{C}$ and $\mathrm{N}$, by Flameless Atomic Ab- 
sorption Spectrometry for As, and by Cold Vapour Atomic Absorption Spectrometry for $\mathrm{Hg}$.

Tab. 1. Conductivity $\left(\mu \mathrm{Sm}^{-1} 18^{\circ} \mathrm{C}\right)$ and major ions $\left(\mu \mathrm{eq} \mathrm{l}^{-1}\right)$ for Lake 20 at Tarn Flat (Guilizzoni et al. 1991, 1992). pH: field measurements; $\mathrm{pH}(\mathrm{A})$ : $\mathrm{pH}$ measurement at ice-melt; $\mathrm{pH}$ (B): $\mathrm{pH}$ after equilibration with atmospheric $\mathrm{CO}_{2}$.

\begin{tabular}{lccc}
\hline & $20 / 12 / 88$ & $24 / 01 / 89$ & $29 / 01 / 89$ \\
\hline $\mathrm{pH}$ & & & 8.06 \\
$\mathrm{pH}(\mathrm{A})$ & 9.23 & 8.20 & 8.40 \\
$\mathrm{pH}(\mathrm{B})$ & 7.62 & 8.20 & 8.20 \\
Alkalinity & 417 & 1682 & 1507 \\
$\mathrm{Cl}^{-}$ & 902 & 437 & 2933 \\
$\mathrm{SO}_{4}^{--}$ & 193 & 162 & 541 \\
$\mathrm{NO}_{3}^{-}$ & 2 & 14 & 8 \\
$\mathrm{NH}_{4}^{+}$ & 1 & 0 & 1 \\
$\mathrm{Ca}^{++}$ & 344 & 2445 & 1158 \\
$\mathrm{Mg}^{++}$ & 238 & 510 & 880 \\
$\mathrm{Na}^{+}$ & 978 & 391 & 2739 \\
$\mathrm{~K}^{+}$ & 51 & 17 & 125 \\
anions & 1515 & 2295 & 4989 \\
cations & 1613 & 3364 & 4903 \\
Conductivity & 161 & 192 & 473 \\
\hline
\end{tabular}

Tab. 2. Nitrogen, phosphorus and silica concentrations for Lake 20 at Tarn Flat (Guilizzoni et al. 1991).

\begin{tabular}{|c|c|c|c|}
\hline & $20 / 12 / 88$ & $24 / 01 / 89$ & 29/01/89 \\
\hline $\mathrm{N}^{-\mathrm{NO}_{3}}{ }^{-}\left(\mu \mathrm{g}^{-1}\right)$ & 30 & 190 & 107 \\
\hline $\mathrm{N}-\mathrm{NH}_{4}^{+}\left(\mu \mathrm{g}^{-1}\right)$ & 9 & 5 & 15 \\
\hline Inorg. $N\left(\mathrm{mg} \mathrm{l}^{-1}\right)$ & 0.04 & 0.20 & 0.12 \\
\hline Org. $\mathrm{N}\left(\mathrm{mg} \mathrm{l}^{-1}\right)$ & 0.12 & 0.00 & 0.10 \\
\hline Total N $\left(\mathrm{mg} \mathrm{l}^{-1}\right)$ & 0.16 & 0.19 & 0.22 \\
\hline Total P $\left(\mu \mathrm{g} \mathrm{^{-1 }}\right)$ & 4 & 0 & 5 \\
\hline $\mathrm{Si}\left(\mathrm{mg} \mathrm{l}^{-1}\right)$ & 3.01 & 1.62 & 7.60 \\
\hline
\end{tabular}

\section{RESULTS AND DISCUSSION}

The chemical analysis of the core (Tab. 3) indicates a mean composition very close to that of anorthosite for $\mathrm{SiO}_{2}, \mathrm{CaO}, \mathrm{MgO}$ and $\mathrm{MnO}$, and to that of granodiorite for $\mathrm{K}_{2} \mathrm{O}, \mathrm{TiO}_{2}$ and $\mathrm{P}_{2} \mathrm{O}_{5}$. These results are consistent with the available information on the lithology of the watershed, which consists mainly of granite, granodiorite, and metamorphic rocks (Carmignani et al. 1987; Libera 1993). However, $\mathrm{Al}_{2} \mathrm{O}_{3}$ is lower than in granodiorite and granite, $\mathrm{Fe}_{2} \mathrm{O}_{3}$ is higher than in monzonite, and $\mathrm{Na}_{2} \mathrm{O}$ is much lower than in any igneous rocks.

In mineralogical terms (D'Argento et al. 1994), the sediments can be described as meta-alluminiferous $\left(\mathrm{Na}_{2} \mathrm{O}+\mathrm{K}_{2} \mathrm{O}<\mathrm{Al}_{2} \mathrm{O}_{3} \quad \mathrm{CaO}\right)$ and alkali - potassic $\left(\mathrm{K}_{2} \mathrm{O} / \mathrm{Na}_{2} \mathrm{O}>1\right)$; according to the International Union of Geological Sciences classification, in the $\mathrm{SiO}_{2}-\mathrm{Na}_{2} \mathrm{O}+$ $\mathrm{K}_{2} \mathrm{O}$ diagram they come into the andesite basaltic category.

For trace elements, such a comparison would be meaningless, since the reported composition of rockforming minerals is highly variable (for instance, according to Salomons \& Förstner (1984) in plagioclase the range for $\mathrm{Cu}$ is $8-700 \mathrm{mg} \mathrm{kg}^{-1}$; for $\mathrm{Zn}, 1-50$; for $\mathrm{Pb}, 1$ 70). However, in general the concentrations of trace elements in Lake 20 sediments are similar to or lower than in "lacustrine sediments" (Salomons \& Förstner 1984) or soils (Bowen 1979), and could by no means pose a threat for living organisms.

To investigate the possibility of contamination due to human influences, the results were also compared with those reported for other Antarctic lakes.

Aceto et al. (1994) looked at the chemical composition of the sediments of Lake Carezza (close to the Italian base, at $74^{\circ} 43^{\prime} \mathrm{S}$ latitude, and $164^{\circ} 03^{\prime} \mathrm{E}$ longitude), along with that of a soil sample taken from the surrounding area (Tab. 4); they found "a very slight and insignificant difference", concluding that anthropogenic alterations are absent or have very limited effects.

The results from Lake 20 reveal much higher concentrations of $\mathrm{Zn}, \mathrm{Cu}$, and possibly $\mathrm{Cr}$, and much lower ones of $\mathrm{Pb}$ and $\mathrm{Ni}$. However, the differences indicated by these data alone might be the result of the different geochemical setting.

From the limnological point of view, the chemical elements detected in a sediment core may be classified in 5 different groups (Kemp et al. 1976): Conservative elements; Nutrients; Carbonate elements; Mobile elements; Enriched elements.

Conservative elements: major elements, like $\mathrm{Si}, \mathrm{Al}$, $\mathrm{Ti}, \mathrm{Na}, \mathrm{K}, \mathrm{Mg}, \mathrm{Cl}$, whose content in the sediments is mainly controlled by the geochemical features of the drainage basin. Their concentrations are very high and seldom affected by direct human influence to any noticeable extent. In fact, in the Lake 20 core they are quite constant (Tab. 5), with a minimum in the 2-4 $\mathrm{cm}$ section (Al, K, Mg, Ti, Na). However, $\mathrm{Si}$ and $\mathrm{Cl}$ show a different pattern: the first decreases slightly from section 16$18 \mathrm{~cm}$ to section $8-10 \mathrm{~cm}$, stabilises as far as section 2-4 $\mathrm{cm}$, then drops sharply in the topmost layer. $\mathrm{Cl}$ shows a marked peak in the 6-8 $\mathrm{cm}$ section.

Nutrients: elements like organic C, P and N, necessary for the growth of aquatic plants. Organic carbon was not measured, but both total $\mathrm{C}$ and $\mathrm{N}$ show a peak at $10-12 \mathrm{~cm}$, then decrease in the 2 to $8 \mathrm{~cm}$ part of the core, and increase again in the $0-2 \mathrm{~cm}$ section, reaching the same concentration as that measured at the bottom of the core. However, P behaves differently, more like the conservative elements, with a minimum at the 2-4 $\mathrm{cm}$ section.

Carbonate elements: carbonate $\mathrm{C}, \mathrm{Ca}$ and the part of $\mathrm{Mg}$ not due to silicates, deriving from the weathering of carbonates in the watershed, or authigenically produced within the waterbody. Since in this study only total carbon was measured (see nutrients), and since $\mathrm{Mg}$ behaves like the other conservative elements, the trend for this group of elements can be described only by referring to $\mathrm{Ca}$. This element shows an increase from the bottom to the top of the core, with a marked peak only in the topmost section. 
Tab. 3. Chemical analysis (dry weight) of the core and reference values after Le Maitre (1976) ${ }^{(1)}$, Bowen (1979) ${ }^{(2)}$, and Salomons \& Förstner $(1984)^{(3)}$.

\begin{tabular}{lcccccccccccccccc}
\hline & $\mathrm{SiO}_{2}$ & $\mathrm{Al}_{2} \mathrm{O}_{3}$ & $\mathrm{CaO}$ & $\mathrm{K}_{2} \mathrm{O}$ & $\mathrm{Fe}_{2} \mathrm{O}_{3}$ & $\mathrm{MgO}$ & $\mathrm{TiO}_{2}$ & $\mathrm{P}_{2} \mathrm{O}_{5}$ & $\mathrm{Na}_{2} \mathrm{O}$ & $\mathrm{MnO}$ & $\mathrm{Cl}$ & $\mathrm{S}$ & $\mathrm{C}$ \\
\hline Core Mean \% & 51.06 & 12.18 & 12.94 & 2.94 & 6.52 & 2.27 & 0.51 & 0.16 & 1.13 & 0.06 & 0.13 & $<0.05$ & 7.36 & 1.75 \\
$\min$ & 37.75 & 8.35 & 8.6 & 1.95 & 3.8 & 1.85 & 0.33 & 0.14 & 0.9 & 0.04 & $<0.05$ & $<0.05$ & 3.39 & 0.13 \\
$\max$ & 54.95 & 13.9 & 19.7 & 3.35 & 7.8 & 2.45 & 0.605 & 0.175 & 1.3 & 0.1 & 0.15 & 0.05 & 14.5 & 5.96 \\
& & & & & & & & & & & & & & & \\
Gabbro $^{(1)}$ & 51.05 & 15.76 & 9.75 & 0.95 & 11.68 & 7.73 & 1.14 & 0.24 & 2.43 & 0.12 & & \\
Anortosite $^{(1)}$ & 51.12 & 26.29 & 12.69 & 0.66 & 3.31 & 2.16 & 0.65 & 0.09 & 3.20 & 0.05 & & \\
Monzonite $^{(1)}$ & 63.65 & 15.9 & 4.24 & 4.13 & 5.42 & 2.05 & 0.79 & 0.25 & 3.79 & 0.10 & & \\
Granodiorite $^{(1)}$ & 66.91 & 15.92 & 3.88 & 2.76 & 4.46 & 1.76 & 0.55 & 0.18 & 3.80 & 0.08 & & \\
Granite $^{(1)}$ & 71.84 & 14.43 & 1.85 & 4.10 & 3.05 & 0.72 & 0.31 & 0.12 & 3.71 & 0.05 & 0.020 & 0.027 & 0.036 & 0.021 \\
Basalt $^{(1)}$ & 45.72 & 14.80 & 10.57 & 1.01 & 14.42 & 7.85 & 3.02 & 0.4 & 3.02 & 0.2 & 0.006 & 0.025 & 0.061 & 0.030 \\
\hline
\end{tabular}

\begin{tabular}{lcccccccc}
\hline & $\mathrm{Zn}$ & $\mathrm{Cu}$ & $\mathrm{Ni}$ & $\mathrm{Mn}$ & $\mathrm{Cr}$ & $\mathrm{Pb}$ & $\mathrm{As}$ & $\mathrm{Hg}$ \\
\hline Core Mean mg kg $^{-1}$ & 101.5 & 59.6 & 12.5 & 442 & 40.4 & $<2$ & 11.65 & 0.066 \\
$\min$ & 49.5 & 18.5 & 4.5 & 348 & 31 & $<2$ & 11.02 & 0.031 \\
$\max$ & 190.5 & 167 & 19.5 & 806 & 45.5 & 2 & 12.68 & 0.141 \\
& & & & & & & & \\
Granite $^{(2)}$ & 52 & 13 & 0.5 & 400 & 4 & 24 & 1.5 & 0.08 \\
Soil $^{(2)}$ & 75 & 50 & 80 & 950 & 100 & 14 & 6 & 0.06 \\
Lacustrine Sediments $^{(3)}$ & 118 & 45 & 66 & 760 & 62 & 34 & & \\
\hline
\end{tabular}

Tab. 4. Comparison with Lake Carezza and Antarctica sediments. (1) Aceto et al. 1994; (2) Cosma et al. 1994

\begin{tabular}{|c|c|c|c|c|c|c|c|c|}
\hline & $\begin{array}{l}\mathrm{Al} \\
(\%)\end{array}$ & $\begin{array}{c}\mathrm{Fe} \\
(\%)\end{array}$ & $\begin{array}{l}\mathrm{Ca} \\
(\%)\end{array}$ & $\begin{array}{l}\mathrm{Mg} \\
(\%)\end{array}$ & $\begin{array}{l}\mathrm{Na} \\
(\%)\end{array}$ & \multicolumn{2}{|c|}{$\begin{array}{c}\mathrm{Mn} \\
\left(\mathrm{mg} \mathrm{kg}^{-1}\right)\end{array}$} & $\mathrm{Fe} / \mathrm{Mn}$ \\
\hline L. 20 (Mean) & 6.45 & 4.56 & 9.250 & 1.371 & 0.841 & \multicolumn{2}{|c|}{442} & 110 \\
\hline L. Carezza ${ }^{(1)}$ & 3.13 & 2.33 & 0.066 & 0.077 & 0.988 & \multicolumn{2}{|c|}{323} & 72 \\
\hline Soil $^{(1)}$ (around L.Carezza) & 3.98 & 2.23 & 0.114 & 0.061 & 0.907 & \multicolumn{2}{|c|}{330} & 68 \\
\hline Antarctica $^{(2)}$ (sea sediments) & & 2.16 & & & & \multicolumn{2}{|c|}{586} & 37 \\
\hline & \multicolumn{2}{|c|}{$\begin{array}{c}\mathrm{Pb} \\
\left(\mathrm{mg} \mathrm{kg}^{-1}\right)\end{array}$} & $\begin{array}{c}\mathrm{Zn} \\
\left(\mathrm{mg} \mathrm{kg}^{-1}\right)\end{array}$ & $\begin{array}{c}\mathrm{Cu} \\
\left(\mathrm{mg} \mathrm{kg}^{-1}\right)\end{array}$ & \multicolumn{2}{|c|}{$\begin{array}{c}\mathrm{Ni} \\
\left(\mathrm{mg} \mathrm{kg}^{-1}\right)\end{array}$} & \multicolumn{2}{|c|}{$\begin{array}{c}\mathrm{Cr} \\
\left(\mathrm{mg} \mathrm{kg}^{-1}\right)\end{array}$} \\
\hline L. 20 (Mean) & \multicolumn{2}{|c|}{$<2$} & 101.5 & 59.6 & \multicolumn{2}{|c|}{12.5} & \multicolumn{2}{|c|}{40.4} \\
\hline L. Carezza ${ }^{(1)}$ & \multicolumn{2}{|c|}{17.9} & 25.8 & 9.88 & \multicolumn{2}{|c|}{16.3} & \multicolumn{2}{|c|}{28.5} \\
\hline Soil $^{(1)}$ (around L.Carezza) & \multicolumn{2}{|c|}{21.3} & 27.5 & 13.4 & \multicolumn{2}{|c|}{17.0} & \multicolumn{2}{|c|}{28.6} \\
\hline Antarctica $^{(2)}$ (sea sediments) & \multicolumn{2}{|c|}{12.7} & 108.0 & 25.3 & \multicolumn{2}{|c|}{24.2} & \multicolumn{2}{|c|}{27.7} \\
\hline
\end{tabular}

Mobile elements: elements like S, Fe, and Mn in the sedimentary environment undergo chemical changes, mainly controlled by $\mathrm{pH}$ and redox conditions, which influence their mobility (increasing or decreasing their solubility). Mobile elements may decrease when the hypolimnion becomes depleted of oxygen and redox conditions favour the reduction to more soluble compounds. $\mathrm{Fe} / \mathrm{Mn}$ ratio. In the core from Lake $20 \mathrm{Fe}$ shows a minimum at the $2-4 \mathrm{~cm}$ section, whereas there is a marked increase in $\mathrm{Mn}$ in the 0-2 cm layer. For $\mathrm{S}$, all data are below the detection limit.

Enriched elements: trace elements $(\mathrm{Cu}, \mathrm{Zn}, \mathrm{Pb}, \mathrm{Cr}$, $\mathrm{Ni}, \mathrm{Hg}, \mathrm{As}$ ) widely used by man in industry, hence liable to be discharged at a rate which greatly exceeds the natural input. In this remote area, as expected, most of these elements behave like conservative elements; however, both $\mathrm{Cu}$ and $\mathrm{Zn}$ have marked peaks at the bottom of the core and at the $4-6 \mathrm{~cm}$ section. $\mathrm{Hg}$ shows a different pattern, with minima at the $4-6$ and $10-12 \mathrm{~cm}$ sections, and a sharp increase in the topmost layer.

Looking to the general chemistry of the sediments, the most prominent feature of the core profiles is the marked increase in $\mathrm{Ca}$ concentration. Since $\mathrm{Mg}$ does not follow the same trend, the $\mathrm{Ca}$ increase could be explained as an enhanced precipitation of $\mathrm{CaCO}_{3}$ induced by an increase in alkalinity occurring during the periods when the lake is ice-covered. Ice cover reduces the exchange with the atmosphere, with a consequent rapid consumption of oxygen due to the decomposition of organic matter (Björck et al. 1993).

The precipitation of $\mathrm{CaCO}_{3}$ may also be the result of a rise in $\mathrm{pH}$ due to photosynthetic activity; before the thaw. In fact, in Lake $20 \mathrm{pH}$ reaches values higher than 10 , then drops almost to 8 , but for most of the time it remains in the range 8.5-9 $\mathrm{pH}$ units (Libera 1993). According to Lawrence and Hendy $(1985,1989)$, biogenic 
Tab. 5. Chemical composition along the Lake 20 core.

\begin{tabular}{|c|c|c|c|c|c|c|c|c|}
\hline $\mathrm{cm}$ & $\begin{array}{l}\mathrm{Si} \\
(\%)\end{array}$ & $\begin{array}{c}\mathrm{Al} \\
(\%)\end{array}$ & $\begin{array}{l}\mathrm{Ca} \\
(\%)\end{array}$ & $\begin{array}{c}\mathrm{K} \\
(\%)\end{array}$ & $\begin{array}{l}\mathrm{Fe} \\
(\%)\end{array}$ & $\begin{array}{l}\mathrm{Mg} \\
(\%)\end{array}$ & $\begin{array}{c}\mathrm{Ti} \\
(\%)\end{array}$ & $\begin{array}{c}\mathrm{Mn} \\
\left(\mathrm{mg} \mathrm{kg}^{-1}\right)\end{array}$ \\
\hline $0-2$ & 17.65 & 5.27 & 14.08 & 2.24 & 4.27 & 1.30 & 0.25 & 806 \\
\hline $2-4$ & 24.08 & 4.42 & 10.90 & 1.62 & 2.66 & 1.12 & 0.20 & 386 \\
\hline $4-6$ & 24.47 & 6.03 & 10.15 & 2.24 & 3.92 & 1.33 & 0.27 & 455 \\
\hline $6-8$ & 23.66 & 6.75 & 10.11 & 2.53 & 4.41 & 1.45 & 0.30 & 404 \\
\hline $8-10$ & 24.03 & 7.04 & 9.47 & 2.66 & 5.18 & 1.48 & 0.32 & 380 \\
\hline $10-12$ & 24.47 & 6.96 & 8.61 & 2.62 & 4.65 & 1.42 & 0.32 & 349 \\
\hline $12-14$ & 25.53 & 6.93 & 7.00 & 2.62 & 5.07 & 1.42 & 0.34 & 383 \\
\hline $14-16$ & 25.27 & 7.36 & 6.79 & 2.78 & 5.42 & 1.45 & 0.35 & 403 \\
\hline \multirow[t]{21}{*}{$16-18$} & 25.69 & 7.25 & 6.15 & 2.70 & 5.46 & 1.39 & 0.36 & 412 \\
\hline & $\mathrm{cm}$ & $\begin{array}{c}\mathrm{S} \\
(\%)\end{array}$ & $\begin{array}{l}\mathrm{Na} \\
(\%)\end{array}$ & $\begin{array}{l}\mathrm{Cl} \\
(\%)\end{array}$ & $\begin{array}{c}\mathrm{P} \\
(\%)\end{array}$ & $\begin{array}{c}\mathrm{N} \\
(\%)\end{array}$ & $\begin{array}{c}\mathrm{C} \\
(\%)\end{array}$ & $\mathrm{C} / \mathrm{N}$ \\
\hline & $0-2$ & $<0.05$ & 0.70 & 0.05 & 0.08 & 0.41 & 6.96 & 16.8 \\
\hline & $2-4$ & $<0.05$ & 0.67 & 0.02 & 0.06 & 0.18 & 3.84 & 21.7 \\
\hline & $4-6$ & $<0.05$ & 0.74 & 0.02 & 0.06 & 0.13 & 3.39 & 26.0 \\
\hline & $6-8$ & $<0.05$ & 0.93 & 0.30 & 0.07 & 0.43 & 3.92 & 9.1 \\
\hline & $8-10$ & $<0.05$ & 0.96 & 0.10 & 0.07 & 1.77 & 10.68 & 6.0 \\
\hline & $10-12$ & $<0.05$ & 0.89 & 0.02 & 0.07 & 5.96 & 14.54 & 2.4 \\
\hline & $12-14$ & $<0.05$ & 0.89 & 0.02 & 0.07 & 3.47 & 7.89 & 2.3 \\
\hline & $14-16$ & $<0.05$ & 0.93 & 0.05 & 0.07 & 1.54 & 7.07 & 4.6 \\
\hline & $16-18$ & $<0.05$ & 0.85 & 0.15 & 0.07 & 1.88 & 7.98 & 4.3 \\
\hline & $\mathrm{cm}$ & $\begin{array}{c}\mathrm{Pb} \\
\left(\mathrm{mg} \mathrm{kg}^{-1}\right)\end{array}$ & $\begin{array}{c}\mathrm{Zn} \\
\left(\mathrm{mg} \mathrm{kg}^{-1}\right)\end{array}$ & $\begin{array}{c}\mathrm{Cu} \\
\left(\mathrm{mg} \mathrm{kg}^{-1}\right)\end{array}$ & $\begin{array}{c}\mathrm{Ni} \\
\left(\mathrm{mg} \mathrm{kg}^{-1}\right)\end{array}$ & $\begin{array}{c}\mathrm{Cr} \\
\left(\mathrm{mg} \mathrm{kg}^{-1}\right)\end{array}$ & $\begin{array}{c}\mathrm{As} \\
\left(\mathrm{mg} \mathrm{kg}^{-1}\right)\end{array}$ & $\begin{array}{c}\mathrm{Hg} \\
\left(\mathrm{mg} \mathrm{kg}^{-1}\right)\end{array}$ \\
\hline & $0-2$ & $<2.0$ & 71.0 & 35.0 & 11.0 & 38.5 & 11.57 & 0.141 \\
\hline & $2-4$ & $<2.0$ & 49.5 & 18.5 & 4.5 & 31.0 & 11.42 & 0.060 \\
\hline & $4-6$ & $<2.0$ & 171.0 & 153.5 & 8.0 & 33.0 & 11.68 & 0.032 \\
\hline & $6-8$ & $<2.0$ & 72.5 & 30.0 & 11.0 & 42.5 & 12.68 & 0.057 \\
\hline & $8-10$ & $<2.0$ & 78.5 & 29.0 & 11.5 & 43.0 & 11.42 & 0.060 \\
\hline & $10-12$ & $<2.0$ & 82.5 & 30.0 & 18.0 & 41.5 & 12.11 & 0.030 \\
\hline & $12-14$ & $<2.0$ & 89.5 & 35.5 & 19.5 & 43.5 & 11.02 & 0.066 \\
\hline & $14-16$ & 2.0 & 108.5 & 37.5 & 14.5 & 45.5 & 11.84 & 0.072 \\
\hline & $16-18$ & $<2.0$ & 190.5 & 167.0 & 14.5 & 45.5 & 11.08 & 0.079 \\
\hline
\end{tabular}

$\mathrm{CO}_{2}$ fixation (by phytoplankton or periphyton) induces the precipitation of carbonate minerals dominated by aragonite, with small amounts of high Mg-calcite.

The Ca contributed by gypsum should be almost negligible, because the $\mathrm{S}$ concentration is always lower than the detection limit of X Ray fluorescence spectrometry $(0.05 \% \mathrm{~S})$.

The main constituents of the sediment, $\mathrm{Si}, \mathrm{Al}, \mathrm{K}, \mathrm{Fe}$, $\mathrm{Ti}$, and the trace elements $\mathrm{Ni}$ and $\mathrm{Cr}$, all show a decreasing pattern from bottom to top the core, possibly due to an increase in the sedimentation of organic matter (acting as a "diluting" factor). In fact, the suggested recent climatic changes (Appleby et al. 1995) may have led to an increase in the primary productivity of the lake. This hypothesis seems to be supported by the increase in $\mathrm{P}$ concentration in the sediments. Moreover, the decrease in the $\mathrm{Fe} / \mathrm{Mn}$ ratio, due to a decrease in $\mathrm{Fe}$ and an increase in $\mathrm{Mn}$, points to a change in the redox conditions at the water - sediment interface induced by an increased load of organic matter.

For Na, the suggested contribution from sea spray (Guilizzoni et al. 1992) does not appear noticeably to influence the sediment chemistry, and the element very likely derives from the weathering of the watershed. In fact, there is no correlation with $\mathrm{Cl}$, which in turn shows some peaks possibly indicating past intrusions of salt water, followed by $\mathrm{Na}$ depletion and $\mathrm{Cl}$ bonding to the organic matter in the sediment (Bowen 1979).

Following another approach, useful suggestions regarding the time changes in the sedimentary environment emerge from an analysis of the metal/aluminium ratios (Bruland et al. 1974; Kemp et al. 1976). Assuming that human influences cannot alter the $\mathrm{Al}$ flux to the sediment, which is mainly due to the natural weathering of the rocks in the drainage basin, the metal/Al ra- 
Tree Diagram for 19 Variables

Ward's method

1-Pearson $r$

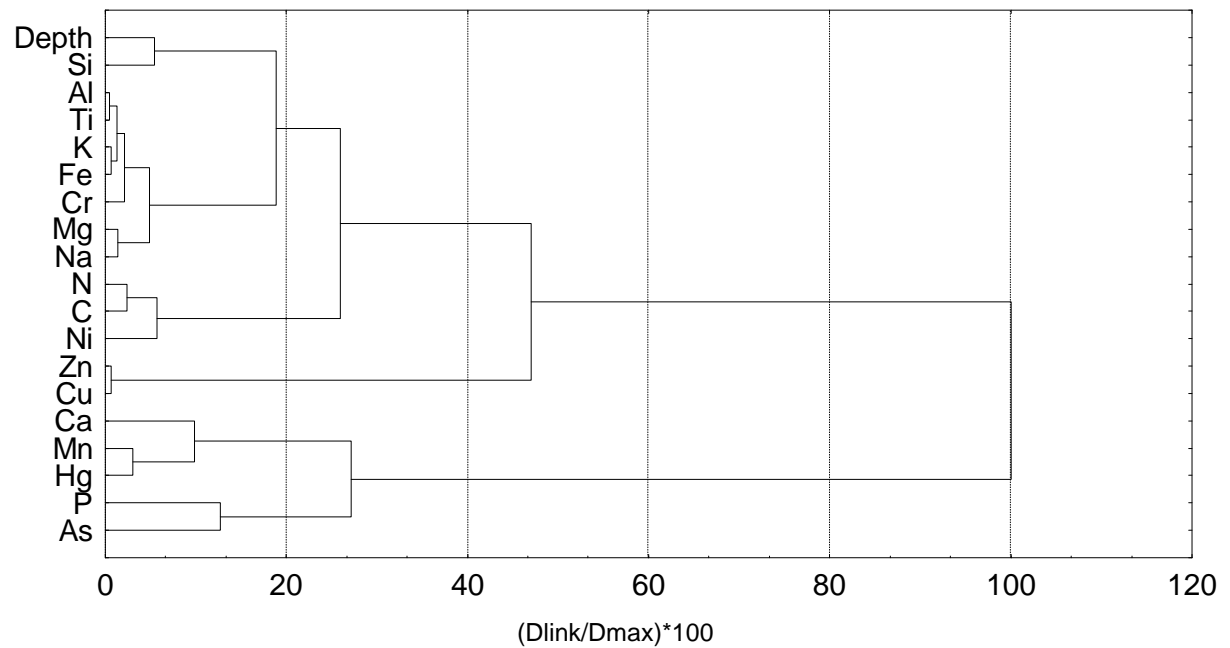

Fig. 1. Cluster analysis of the Lake 20 core.

tios will in fact change only if the metal and $\mathrm{Al} \mathrm{accu}-$ mulate in the sediments at different rates.

This approach confirms that the $\mathrm{Ca}, \mathrm{Mn}$, and $\mathrm{Hg}$ accumulations show a marked divergence from that of $\mathrm{Al}$, whereas for the other elements the sedimentation more closely follows that of the conservative element $\mathrm{Al}$.

The cluster analysis (Fig. 1) also shows the common geochemical relationship of $\mathrm{Al}, \mathrm{Ti}, \mathrm{K}, \mathrm{Fe}$, and $\mathrm{Cr}$ (clay constituents), and between $\mathrm{P}$ and As; in addition, there is a cluster formed of Ca and Mn. Björck et al. (1993) attributed this relationship to the precipitation of mixed carbonates, calcite and rhodochrosite. $\mathrm{Hg}$ too seems to be associated with this cluster, probably for a co-precipitation of this element with autochthonous carbonates.

\section{CONCLUSIONS}

Radiocarbon dating (Orombelli, personal communication) indicates that the bottom of a $20 \mathrm{~cm}$ core from Lake 20 has an age of $1500 \pm 50$ years BP. As a rough estimate, the average sedimentation rate therefore corresponds to $0.013 \mathrm{~cm} \mathrm{y}^{-1}$, well in agreement with the reported rate of sedimentation, in the order of $0.1 \mathrm{~cm} \mathrm{y}^{-1}$ or lower, for other lakes in Antarctica (Nedell et al. 1987; Squyres et al. 1991; Björck et al. 1993; Doran et al. 1994; Appleby et al. 1995).

According to Lyons et al. (1985), the increase in organic carbon and carbonates could be due to cold and/or dry periods, when the freeze-drying of the lake water and a reduced inflow decrease the ratio of allochtonous material to authigenically and biogenically produced material in the sediments.

Doran et al. (1994) report that a prolonged cold/dry period lasted between 1800 and $1500 \mathrm{y} \mathrm{BP}$, and another one has been identified prior to $1200 \mathrm{y}$ BP. Possibly, the high measured total $\mathrm{C}$ values (organic + carbonate carbon) at the bottom of the core from Lake 20, and the peak at the $10-12 \mathrm{~cm}$ section, are related to these dry periods. The increase in total carbon is probably due to the high productivity of the lake, resulting in the sedimentation of organic matter of predominantly autochtonous origin, as reflected by the low $\mathrm{C} / \mathrm{N}$ ratio (Björck et al. 1993).

On the other hand, the drop in $\mathrm{Cl}$, from the maximum at the $6-8 \mathrm{~cm}$ section to the minimum at the 4-6 $\mathrm{cm}$ section, could be related to a wet period (resulting in a rise in the water level in lakes), that lasted between 750 and 400 y BP (Doran et al. 1994).

Considering that each sediment section probably covers at least 150 years, the highest concentrations for $\mathrm{Zn}$ and $\mathrm{Cu}$, detected in the $4-6 \mathrm{~cm}$ section, definitely date back to the pre-industrial period. Hence, they reflect an increase in rock weathering/element sedimentation, rather than a contamination.

Björck et al. (1993) observed a higher erosional input in the period following the deposition of a tephra layer, dated at 720 y BP. For the Lake 20 core, the hypothesis of an increased sedimentation of allochtonous material around that time, at the $4-6 \mathrm{~cm}$ section, is further supported by the high $\mathrm{C} / \mathrm{N}$ ratio of this section, explained by the input of allochtonous organic compounds (Björck et al. 1993).

Finally, the minimum at the $2-4 \mathrm{~cm}$ section, followed by the increase in the top layer of the sediments, may be due to climate warming over the past century, leading to greater erosion and increased precipitation of autochtonous material (Appleby et al. 1995). 
In conclusion, the analysis of the sediment core from Lake 20 indicates that the chemical composition of the sediments is consistent with the known geochemical characteristics of the drainage basin, although it is true that the sedimentation rate in Lake 20 has changed in time. The variations along the core are most probably related to the climatic evolution of the area, to the consequent changes in weathering processes, and possibly to an increase in the primary productivity of the lake, rather than to anthropogenic influences on the biogeochemical cycles of the elements. It is only for $\mathrm{Hg}$ that the sharp increase in the topmost layer could suggest the long range transport of this contaminant.

\section{ACKNOWLEDGMENTS}

We would like to thank the crew of the Italian Base in Antarctica for their logistic support, and the Italian National Research Programme in Antarctica, Environmental Contamination Project 2a, Glaciology and Paleoclimate, for partially funding this research.

\section{REFERENCES}

Aceto, M., C. Sarzanini, O. Abollino, G. Sacchero \& E. Mentasti. 1994. Distribution of minor and trace metals in Carezza Lake (Antarctica) ecosystem. Intern. J. Environ. Anal. Chem., 55: 165-177.

Appleby, P.G., V.J. Jones \& J.C. Ellis-Evans. 1995. Radiometric dating of lake sediments from Signy Island (maritime Antarctic): evidence of recent climatic change. $J$. Paleolimnol., 13: 179-191.

Björck, S., H. Håkansson, S. Olsson, L. Barnekow \& J. Janssens. 1993. Palaeoclimatic studies in South Shetland Islands, Antarctica, based on numerous stratigraphic variables in lake sediments. J. Paleolimnol., 8: 233-272.

Bowen. H.J.M. 1979. Environmental Chemistry of the elements. Academic Press: 333 pp.

Bruland, K.W., K. Bertine, M. Koide \& E.D. Goldberg. 1974 History of metal polution in Southern California coastal zone. Environ. Sci. Technol., 8: 425-432.

Carmignani, L., C. Ghezzo, G. Bosso, B. Lombardo, M. Meccheri, A. Montrasio, P.C. Pertusati \& F. Salvini. 1987. Geological map of the area between David and Mariner glaciers Victoria Land (Antarctica). Programma Nazionale di Ricerche in Antartide, CNR-ENEA.

Cosma, B., F. Soggia, M.L. Abelmoschi \& R. Frache. 1994. Determination of trace metals in Antarctic sediments from
Terra Nova Bay - Ross Sea. Intern. J. Environ. Anal. Chem., 55: 121-128.

D’Argento, B., F. Innocenti \& F.P. Sassi. 1994. Introduzione allo Studio delle Rocce. UTET: $162 \mathrm{pp}$.

Doran, P.T., R.A. Wharton, Jr. \& W.B. Lyons. 1994. Paleolimnology of the McMurdo Dry Valleys, Antarctica. $J$. Paleolimnol., 19: 85-114.

Guilizzoni. P., V. Libera, G. Tartari, R. Mosello, D. Ruggiu, M. Manca, A. Nocentini, M. Contesini, P. Panzani \& M. Beltrami. 1991. Indagine per una caratterizzazione limnologica di ambienti lacustri antartici. In: Atti del Primo Convegno di Biologia Antartica. Roma, CNR, 22-23 giugno 1989: 377-408.

Guilizzoni. P., V. Libera, M. Manca, R. Mosello, D. Ruggiu \& G.A. Tartari. 1992. Preliminary results of limnological research in Terra Nova Bay area (Antarctica). In: R. Mosello, B.M. Wathne and G. Giussani (Eds), Limnology on groups of remote lakes: ongoing and planned activities. Documenta Ist. Ital. Idrobiol., 32: 107-120.

Heywood, R.B. 1984. Antarctic inland waters. In: R.M. Laws (Ed.), Antarctic Ecology. Academic Press, Vol. 1: 279344.

Kemp, A.L.W., R.L. Thomas, C.I. Dell \& J.M. Jacquet. 1976. Cultural impact on the geochemistry of sediments in Lake Erie. J. Fish. Res. Board Can., 33: 440-462.

Lawrence, M.J.F. \& C.H. Hendy. 1985. Water column and sediment characteristics of Lake Fryxell, Taylor Valley, Antarctica. N.Z.J. Geol. Geophys., 28: 543-552.

Lawrence, M.J.F. \& C.H. Hendy. 1989. Carbonate deposition and the Ross Sea ice advance, Fryxell basin, Taylor Valley, Antarctica. N.Z.J. Geol. Geophys., 32: 267-277.

Le Maitre, R.W. 1976. Chemical variability of some common igneous rocks. J. Petrol., 17: 589-637.

Libera, V. 1993. Osservazioni fisico-limnologiche su un lago Antartico nell'ambito di una ricognizione dei corpi d'acqua dolce nell'area di Baia Terra Nova. In: Atti del Seminario su "Il ruolo delle aree remote nello studio dei cambiamenti globali". Roma, CNR, 23 Marzo 1993: 133139.

Lyons, W.B., P.A. Mayewski, P. Donahue \& D. Cassidy. 1985. A preliminary study of the sedimentary history of Lake Vanda, Antarctica: climatic implications. N.Z. J. Mar. Freshwat. Res., 19: 253-260.

Nedell, S.S., D.W. Andersen, S.W. Squyres \& F.G. Love. 1987. Sedimentation in ice-covered Lake Hoare, Antarctica. Sedimentology, 34: 1093-1106.

Salomons, W. \& U. Förstner. 1984. Metals in the Hydrocycle. Springer-Verlag: $349 \mathrm{pp}$.

Squyres, S.W., D.W. Andersen, S.S. Nedell \& R.A. Wharton, Jr. 1991. Lake Hoare, Antarctica: sedimentation through a thick perennial ice cover. Sedimentology, 38: 363-379. 